\title{
BROWN SEAWEED MEAL TO NILE TILAPIA FINGERLINGS
}

\author{
ALGA MARINHA MARROM PARA ALEVINOS DE TILÁPIA DO NILO
}

\author{
Costa, M.M. ${ }^{1 A}$; Oliveira, S.T.L. ${ }^{1 B} ;$ Balen, R.E. ${ }^{2 *}$; Bueno Junior, G. ${ }^{3 A}$; Baldan, L.T. ${ }^{2 A}$; \\ Silva, L.C.R. ${ }^{3 \mathrm{~B}}$ and Santos, L.D. ${ }^{3 \mathrm{C}}$
}

\begin{abstract}
'Laboratório de Microbiologia e Imunologia Animal. Universidade Federal do Vale do São Francisco, UNIVASF. Petrolina, PE. Brazil. Amateus.costa@univasf.edu.br; Bmmatiuzzi@univasf.edu.br ${ }^{2} Z$ Zoologia. Universidade Federal do Paraná, UFPR. Centro Politécnico. Setor de Ciências Biológicas. Curitiba, PR. Brazil. *rebalen@yahoo.com.br; Abaldanlt@ufpr.br

${ }^{3}$ Aquicultura e Desenvolvimento Sustentável. Universidade Federal do Paraná, UFPR. Palotina, PR. Brazil. Agilsonjbueno@yahoo.com.br; BIcrsilva@ufpr.br; Cliliansantos@ufpr.br
\end{abstract}

\section{AdDitional KEYWORDS}

Ascophyllum nodosum. Feed additive. Fish nutrition. Oreochromis niloticus.

\section{SUMMARY}

This work evaluated the effects of increasing levels of the brown seaweed Ascophyllum nodosummeal (BSM) in the feed given to Nile tilapia Oreochromis niloticus fingerlings. The completely randomized design experiment lasted 42 days. Nile tilapia fingerlings $(n=75)$ with an average age of 30 days and average weight of $0.43 \pm 0.02 \mathrm{~g}$ were assigned to 25 plastic tanks and submitted to five treatments in five repetitions. The treatments were increasing levels of $\operatorname{BSM}(5,10,15$, and 20 $\mathrm{g} \mathrm{kg}^{-1}$ of feed) and a control feed (no BSM). Each experimental unit was made up of a $36 \mathrm{~L}$ plastic tank with three fingerlings. The parameters studied were final average weight, percentage of weight gain, apparent feed conversion ratio, total length and carcass yield with and without head. The final average weight, percentage of weight gain, and total length were not affected by the treatments $(p>0.05)$. The apparent feed conversion ratio improved linearly $(p<0.01)$ and carcass yield increased linearly $(p<0.01)$ as the BSM in feeds increased. BSM is an additive with potential use in Nile tilapia feed at the level of $20 \mathrm{~g} \mathrm{~kg}^{-1}$ because it does not result in growth loss and improves the feed conversion ratio and carcass yield in Nile tilapia during the fingerling period.

\section{RESUMO}

Este trabalho avaliou os efeitos de níveis

\section{PaLAVRAs chaVe ADICIONAIS}

Ascophyllum nodosum. Aditivo alimentar. Nutrição de peixes. Oreochromis niloticus.

crescentes da farinha de alga marrom Ascophyllum nodosum (FAM) nas rações para alevinos de tilápia do Nilo Oreochromis niloticus. O experimento, com delineamento inteiramente casualizado, durou 42 dias. Foram utilizados alevinos de tilápia do Nilo $(n=75)$ com idade média de 30 dias e peso médio de $0,43 \pm 0,02 \mathrm{~g}$, distribuídos em 25 tanques plásticos submetidos à cinco tratamentos e cinco repetições. Os tratamentos foram níveis crescentes de farinha de alga marrom $(5,10,15$ e $20 \mathrm{~g} \mathrm{~kg}^{-1}$ de ração) e uma ração controle (sem FAM). Cada unidade experimental foi composta por um tanque plástico de $36 \mathrm{~L}$ com três alevinos. Foram estudados os parâmetros médios de peso final, percentagem de ganho de peso, taxa de conversão alimentar aparente, comprimento total e rendimento de carcaça, com e sem cabeça. As médias de peso final, percentagem de ganho de peso e comprimento total não foram influenciadas pelos tratamentos $(p>0,05)$. Os valores da taxa de conversão alimentar aparente melhoraram linearmente $(p<0,01)$ e os valores de rendimento de carcaça aumentaram linearmente $(p<0,01)$ à medida que se aumentaram os níveis de FAM nas rações. A farinha de alga marrom é um aditivo com potencial utilização em rações de tilápia do Nilo no nível de $20 \mathrm{~g} \mathrm{~kg}^{-1}$, pois não diminui o crescimento e promove melhora da taxa de conversão alimentar e do rendimento de carcaça de alevinos de tilápia do Nilo. 


\section{INTRODUCTION}

Brazil's large territory, extensive hydrologic basin, and weather make it suitable for raising tropical fish species, such as Nile tilapia, Oreochromis niloticus, while producing large amounts of feed raw materials. The Brazilian semi-arid northeast is one of the regions with excellent conditions for breeding tilapia, despite its low rainfall. As such, fish culture is a potential economic activity in that area.

The presence of some rivers, particularly the São Francisco River and its dams, irrigation canals and lakes, affords suitable conditions for setting up fish production systems. The proximity to sites of production of raw materials for the manufacture of feeds (west of Bahia State) is a positive factor for the development of fish culture in the region (Meurer et al., 2010).

From the social viewpoint, fish culture may become an important income source for the local population, particularly for riverside populations such as small-scale fishers, who can hold regular jobs in both large firms and work in small production associations or cooperatives. The culture of species such as the Nile tilapia is an important alternative in the region, as the culture technology for this has been fully mastered (Meurer et al., 2009).

Brown seaweed (Ascophyllum nodosum) is commonly found on the North Atlantic shore (Branden et al., 2007). It is commercially used in the manufacture of agricultural and animal rearing products (Fleurence, 1999). According to Nakagawa et al. (1997), A. nodosum may also be a good additive to fish feeds.

Brown seaweed meal was obtained as a very fine powder with a light cream color. According to the manufacturer, it is composed of $87 \%$ dry matter, $6 \%$ crude protein, 6 $\%$ crude fiber, $22 \%$ mineral matter, $3 \%$ ether extract, and $50 \%$ carbohydrates; however, composition may vary as a function of fresh seaweed composition (Sharp, 1986).
The dietary addition of $A$. nodosum to feeds results in the improvement of animal performance, immunity and meat quality; however, most reports of this have been in terrestrial animals (Allen et al., 2001; Turner et al., 2002; Leupp etal., 2005; Archer et al., 2007; Branden et al., 2007; Kannan et al., 2007a; Kannan et al., 2007b; Gardiner et al., 2008). Despite the evidence regarding the use of A. nodosum in terrestrial animals, its use in fish has been little studied.

The Nile tilapia is an important species for fish culture in the world and the most commonly cultured fresh water specie in Brazil (El-Sayed, 2006). Due to the importance of this fish species and the benefits that $A$. nodosum may confer upon Nile tilapia culture, the present study evaluated the effects of brown seaweed meal inclusion in Nile tilapia fingerling feed on the performance, survival rate and carcass yield.

\section{MATERIAL AND METHODS}

The present study was carried out in the Aquaculture Laboratory of the Zootechnics Collegiate of Universidade Federal do Vale do São Francisco (UNIVASF), Agrarian Science Campus at Petrolina, PE, Brazil to test the use of increasing levels of brown seaweed meal (BSM) A. nodosum in feeds for sexually reversed Nile tilapia fingerlings of the chiltralada breed.

A lot of 300 sexually reversed Nile tilapia fingerlings in the initial phase of development and aged 30 days, from the Bebedouro Fish Farm run by the $3^{\text {rd }}$ Regional Superintendence of CODEVASF at Petrolina, PE, were placed in a $1000 \mathrm{~L}$ tank with constant aeration and water circulation. The fishes received feed with $30 \%$ of digestible protein (DP) and $3000 \mathrm{kcal} \mathrm{kg}^{-1}$ of digestible energy (DE) without BSM for one week.

It were took 75 fingerlings with an average weight of $0.43 \pm 0.02 \mathrm{~g}$ from the initial lot and assigned them to 25 plastic tanks with $36 \mathrm{~L}$ water in a completely random design with five treatments and five 


\section{BROWN SEAWEED MEAL TO NILE TILAPIA FINGERLINGS}

repetitions. Each experimental unit was made up of a plastic tank with three fingerlings. The experimetal period was 42 days.

The water of the plastic tanks was constantly aerated with microporous stones and a mini air compressor. The experimental management involved daily morning (7:00 h) and afternoon $(16: 30 \mathrm{~h})$ siphoning with the removal of $40 \%$ water. Feces and the unconsumed feed were also removed. The internal tank walls were cleaned weekly to prevent the appearance of periphyton.

The treatments used in the present work were five feeds, four with increasing amounts of $\operatorname{BSM}\left(5,10,15\right.$, and $20 \mathrm{~g} \mathrm{~kg}^{-1}$ feed) and a control feed (without the addition of BSM). Five feed formulations with $30 \%$ of DP and $3000 \mathrm{kcal} \mathrm{kg}^{-1}$ of DE were prepared (Boscolo et al., 2002; Meurer et al., 2003). The feed ingredients were ground and sieved through a $1 \mathrm{~mm}$ mesh, except BSM, which was already a fine powder.

Feed formulations are given in table $\mathbf{I}$. After mixing, the feeds were pelletized in an experimental electric pelletizer and the pellets were dried in a forced air oven at $56^{\circ} \mathrm{C}$ for $24 \mathrm{~h}$. After drying, the pellets were crushed, and sorted in fractions by diameters

Table I. Percent composition of feeds. (Composição percentual das dietas).

\begin{tabular}{|c|c|c|c|c|c|}
\hline & \multicolumn{5}{|c|}{ Ascophyllum nodosum ( $\mathrm{g} \mathrm{kg}^{-1}$ feed) } \\
\hline & 0.00 & 5.00 & 10.00 & 15.00 & 20.00 \\
\hline \multicolumn{6}{|l|}{ Ingredients } \\
\hline Soybean meal & 70.79 & 70.89 & 71.19 & 71.29 & 71.39 \\
\hline Maize & 16.70 & 15.80 & 14.80 & 13.90 & 13.00 \\
\hline Soybean oil & 5.00 & 5.30 & 5.50 & 5.80 & 6.10 \\
\hline Dicalcic phosphate & 2.80 & 2.80 & 2.80 & 2.80 & 2.80 \\
\hline Calcitic lime & 0.20 & 0.20 & 0.20 & 0.20 & 0.20 \\
\hline Ascophyllum nodosum ${ }^{1}$ & 0.00 & 0.50 & 1.00 & 1.50 & 2.00 \\
\hline Mineral and vitamin supplement ${ }^{2}$ & 24.00 & 4.00 & 4.00 & 4.00 & 4.00 \\
\hline Salt (NaCl) & 0.50 & 0.50 & 0.50 & 0.50 & 0.50 \\
\hline Butyl hydroxyl toluene (BHT) & 0.01 & 0.01 & 0.01 & 0.01 & 0.01 \\
\hline Total & 100.00 & 100.00 & 100.00 & 100.00 & 100.00 \\
\hline \multicolumn{6}{|l|}{ Chemical composition³ (\%) } \\
\hline Linoleic acid & 3.52 & 3.65 & 3.78 & 3.91 & 4.04 \\
\hline Starch & 19.95 & 19.40 & 18.85 & 18.30 & 17.74 \\
\hline Calcium & 1.00 & 1.00 & 1.00 & 1.00 & 1.00 \\
\hline Digestible energy (kcal kg $\left.{ }^{-1}\right)$ & 3000.00 & 3000.00 & 3000.00 & 3000.00 & 3000.00 \\
\hline Crude fiber & 4.51 & 4.54 & 4.56 & 4.58 & 4.60 \\
\hline Phosphorus & 0.97 & 0.97 & 0.97 & 0.97 & 0.97 \\
\hline Fat & 6.62 & 6.87 & 7.12 & 7.36 & 7.61 \\
\hline Lysine & 2.01 & 2.01 & 2.01 & 2.02 & 2.02 \\
\hline Methionine + cystine & 0.96 & 0.96 & 0.96 & 0.96 & 0.95 \\
\hline Digestible protein & 30.00 & 30.00 & 30.00 & 30.00 & 30.00 \\
\hline Crude protein & 33.54 & 33.56 & 33.58 & 33.61 & 33.63 \\
\hline
\end{tabular}

${ }^{1}$ From Valeagro Comércio e Distribuição de Produtos Agropecuários Ltda.; ${ }^{2}$ Warranty levels per product kilogram: Vit. A, 1200000 UI; Vit. D3, 200000 UI; Vit. E, 12000 mg; Vit. K3, 2400 mg; Vit. B1, 4800 mg; Vit. B2, $4800 \mathrm{mg}$; Vit. B6, $4000 \mathrm{mg}$; Vit. B12, $4800 \mathrm{mg}$; Folic acid, $1200 \mathrm{mg}$; Pantotenate Ca, $12000 \mathrm{mg}$; Vit. C, 48000 mg; Biotin, 48 mg; Coline, 65000 mg; Niacin, 24000 mg; Fe, 10000 mg; Cu, 6000 mg; Mn, 4000 mg; Zn, 6000 mg; I, 20 mg; Co, 2 mg; Se, 20 mg. ${ }^{3}$ According to Rostagno et al. (2000). 
appropriate for fingerling bite.

The fingerlings were fed three times a day at 8:00,12:00 and 17:00 $\mathrm{h}$ at $10 \%$ of their live weight. Every week, the experimental units were weighed for correction of diet amounts.

A BSM sample was sent to the Animal Nutrition Laboratory of UNIVASF for chemical analysis (Silva and Queiroz, 2002). The percent moisture, mineral matter, ether extract, crude protein and crude energy (kcal $\mathrm{kg}^{-1}$ ) values found (as feed basis) were 9.64, $22.34,2.49,7.70$, and 2826.99, respectively. The BSM values agree with those reported by Sharp (1986) and are close to the manufacturer's specifications.

The water oxygen concentration (oxymeter model Oxy-Check HI 9147, HANNA Instruments) and temperature were measured daily before siphoning. Water $\mathrm{pH}$ (pHmeter model Combo HI 98130, HANNA Instruments) and electric conductivity (conductometer model CA 150p TECNOPON Special Equipment Ltd.) were measured weekly before siphoning.

The mean values of morning and afternoon water temperature were, respectively, $28.6 \pm 0.5^{\circ} \mathrm{C}$ and $29.6 \pm 0.6^{\circ} \mathrm{C}$, and of $\mathrm{pH}$, dissolved oxygen and electric conductivity were $7.4 \pm 0.4,5.7 \pm 0.9 \mathrm{mg} \mathrm{L}^{-1}$, and 109.7 $\pm 7.4 \mu \mathrm{Sm} \mathrm{cm}^{-1}$, respectively. These parameters did not vary with treatments $(\mathrm{p}>0.05)$. The mean values of physical-chemical parameters of the plastic tank water noted above ( $\mathrm{pH}$, dissolved oxygen, electric conductivity, and morning and afternoon temperature) remained within the recommended values for the species (El-Sayed, 2006).

The fishes of the experimental units were individually weighed and measured weekly for correction of feed amounts and evaluation of growth. At the end of the experimental period (42 days), the fingerlings of all experimental units were counted, weighed and measured individually to determine the average survival rate, average final weight, percentage of weight gain, apparent feed conversion ratio, average length, head length, height, and breadth. Later, the fingerlings were stunned with cold water $\left(2^{\circ} \mathrm{C}\right)$, slaughtered and gutted for evaluation of percent carcass yield with and without heads.

The studied parameters were submitted to variance analysis and, when the differences were significant at the 0.05 level, to regression testing with SAEG (Statistical and Genetic Analysis System) software (UFV, 2000).

\section{RESULTS AND DISCUSSION}

The survival ratio during the experimental period was $100 \%$ in all experimental units. The mean initial weight, final weight, and weight gain values of Nile tilapia fingerlings submitted to feeds with increasing levels of BSM are given in table II. The initial weight of fingerlings used in the experiment was statistically similar $(p>0.05)$ across treatments. Likewise, the mean final weight and weight gain did not differ significantly $(p>0.05)$ among treatments.

The mean apparent feed conversion

Table II. Mean final values of performance in Nile tilapia fingerlings submitted to feeds with increasing levels of brown seaweed (A. nodosum) meal during 42 days. (Valores médios finais do desempenho para alevinos de tilápia do Nilo submetidos a dietas com níveis crescentes de farinha de alga marinha marrom ( $A$. nodosum) durante 42 dias).

\begin{tabular}{lccc}
\hline & \multicolumn{3}{c}{ Weight $(\mathrm{g})$} \\
BSM & Initial & Final & Gain \\
\hline 0 & 0.42 & 3.76 & 3.34 \\
5 & 0.43 & 4.27 & 3.85 \\
10 & 0.43 & 4.26 & 3.83 \\
15 & 0.43 & 4.29 & 3.86 \\
20 & 0.42 & 5.19 & 4.71 \\
CV & 4.49 & 21.64 & 23.44 \\
\hline
\end{tabular}

$\mathrm{BSM}=$ Brown seaweed meal $(A$. nodosum) $\mathrm{g}$ $\mathrm{kg}^{-1}$ feed; $C V=$ Coefficient of variation. 


\section{BROWN SEAWEED MEAL TO NILE TILAPIA FINGERLINGS}

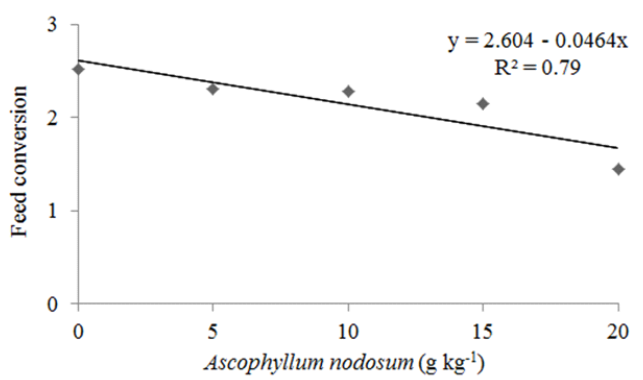

Figure 1. Apparent feed conversion ratio of Nile tilapia (O. niloticus) submitted to feeds with increasing levels of brown seaweed (A. nodosum) meal during 42 days. (Conversão alimentar aparente da tilápia do Nilo (O. niloticus) submetidos a rações com níveis crescentes de farinha de alga marinha marrom ( $A$. nodosum) durante 42 dias).

(FCa) in Nile tilapia fingerlings showed a significant $(p<0.01)$ linear improvement as a function of the increased levels of BSM in feeds (figure 1).

The final standard length, head length, height and body width of Nile tilapia

Table III. Mean final values (cm) of body parameters of Nile tilapia submitted to feeds with increasing levels of brown seaweed (A. nodosum) meal during 42 days. (Valores finais médios $(\mathrm{cm})$ de parâmetros corporais da tilápia do Nilo submetidas a dietas com níveis crescentes de farinha de alga marinha marrom ( $A$. nodosum) durante 42 dias).

\begin{tabular}{lcccc}
\hline $\mathrm{BSM}^{1}$ & $\mathrm{SL}$ & $\mathrm{HL}$ & $\mathrm{BH}$ & $\mathrm{BW}$ \\
\hline 0 & 5.03 & 1.73 & 1.74 & 0.93 \\
5 & 5.37 & 1.85 & 1.84 & 0.97 \\
10 & 5.25 & 1.83 & 1.80 & 1.02 \\
15 & 5.33 & 1.83 & 1.82 & 0.94 \\
20 & 5.19 & 1.82 & 1.77 & 0.92 \\
$\mathrm{CV}$ & 7.35 & 7.98 & 8.94 & 12.07 \\
\hline
\end{tabular}

$\mathrm{BSM}=$ Brown seaweed meal $(A$. nodosum $) \mathrm{g} \mathrm{kg}^{-1}$ feed; $\mathrm{SL}=$ Standard length; $\mathrm{HL}=$ Head length; $\mathrm{BH}=$ Body height; $\mathrm{BW}=$ Body width. $\mathrm{CV}=$ Coefficient of variation.

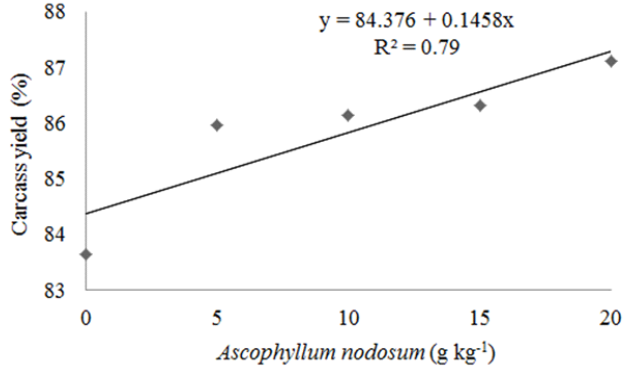

Figure 2. Carcass yield of Nile tilapia fingerlings submitted to feeds with increasing levels of brown seaweed (A. nodosum) meal during 42 days. (Rendimento de carcaça de alevinos de tilápia do Nilo submetidos a dietas com níveis crescentes de farinha de alga marinha marrom (A. nodosum) durante 42 dias).

fingerlings submitted to feeds with increasing levels of BSM did not vary significantly ( $p>0.05$ ) among treatments (table III).

The final carcass yields, with and without heads, of Nile tilapia fingerlings increased linearly and significantly $(\mathrm{p}<0.01)$ with the increasing BSM levels (figures $\mathbf{2}$ and $\mathbf{3}$ ).

The effect of BSM on the final weight found in the present work corroborates the

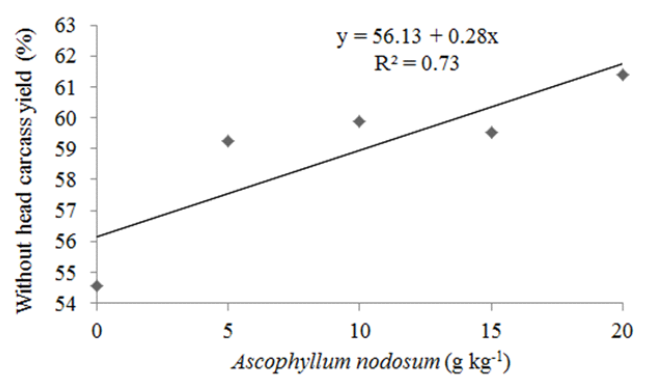

Figure 3. Without head carcass yield of Nile tilapia fingerlings submitted to feeds with increasing levels of brown seaweed (A. nodosum) meal during 42 days. (Rendimento de carcaça sem cabeça de alevinos de tilápia do Nilo submetidos a dietas com níveis crescentes de farinha de alga marrom ( $A$. nodosum) durante 42 dias). 
results reported by Nakagawa et al. (1997) for red sea bream (Pargus major) fingerlings. The weight of fingerlings administered feeds containing $2 \%$ BSM did not vary significantly compared with the control treatment; however, the $5 \%$ BSM treatment resulted in a larger final weight. The data in the present work differ from those of Alves Filho et al. (2011), who observed a decrease in weight gain in fingerlings of Nile tilapia (O. niloticus) at brown seaweed (A. nodosum) level of $3 \%$, and Davies et al. (1997), in juvenile grey mullet (Chelon labrosus) at red seaweed (Porphyra purpurea) levels of $0,16.5$, and $33 \%$.

The FCa of Nile tilapia given increasing levels of BSM during the experimental period differs from the results obtained by Nakagawa et al. (1997) for red sea bream fingerlings. Likewise, Davies et al. (1997) found poorer FCa values for juvenile grey mullet given feeds with high levels of red seaweed meal compared with control treatment results.

The standard length results for fingerlings also agree with the results reported by Nakagawa et al. (1997), in which the length of red sea bream administered feeds containing $2 \%$ BSM was statistically similar to that of control fish. The carcass yields with and without head differed from those reported by Nakagawa et al. (1997), which did not reveal any difference in percent muscle ratio. Moreover, Alves Filho et al. (2011) asserted no significant effect of BSM levels on carcass weight without viscera. Nevertheless, the present results corroborate those obtained by Mustafa et al. (1995), who demonstrated that BSM resulted in increased muscle protein deposition in red sea bream. Despite the difference in parameter values, a larger muscle and/or protein deposition is generally related to better carcass yields.

The FCa is related to the live weight gain afforded by ingested food. In this experiment, the feed was pelletized with $10 \%$ moisture, which is substantially lower than the $75 \%$ body water of fish (Meurer et al., 2007). Therefore, the FCa may be influenced by the type of biomolecule or tissue deposited in the fish body. If the deposition occurs preferentially as lean tissue, the dry feed is converted to tissue with high water concentration, which improves the FCa. When deposition occurs as fat, as it does not have water, the FCa values are lower.

The FCa and carcass yield results obtained are consistent with each other, as the fat deposition in Nile tilapia generally occurs in viscera, which are removed for carcass analysis. Thus, it can be expected that a longer experimental period will result in better FCa values, and significantly better weight and weight gain values with BSM treatments.

The better FCa and carcass yield afforded by the treatments may be related to the BSM composition. Fike et al. (2005) stated that the bioavailability of microminerals, vitamins, antioxidants, and other metabolites present in A. nodosum may affect animal performance positively. Kumar et al. (2008) reported that microalgae have bioactive compounds, such as phycocolloids, minerals, vitamins, carotenoids, and $\mathrm{n} 3$ fatty acids, thus playing both a nutritional and medicinal role.

Another important factor pointed out in the literature is the immune stimulating role of BSM. According to Berteau and Mulloy (2003), brown seaweed has a large amount of sulphated fucans, which are oligosaccharides that act on the immune system. Saker et al. (2004) claim that the extract of $A$. nodosum has a positive effect on the immune system of ruminants. Among the few studies on fish, those of Gabrielsen and Austreng (1998) revealed that alginate from $A$. nodosum, used as an agglutinant in Atlantic salmon feed, had an immune stimulant effect with significantly increased levels of lysozyme in plasma. In addition, Nakagawa et al. (1997) reported that A. nodosum improved the physiological condition of fish.

Despite these encouraging results, 


\section{BROWN SEAWEED MEAL TO NILE TILAPIA FINGERLINGS}

further research is necessary to determine the levels for the maximal development of the species, given the linear improvement in $\mathrm{FCa}$ and carcass yield with the addition of BSM. However, one should not expect an indication of much higher levels for Nile tilapia in this phase, as, according to Davies et al. (1997), the use of high levels of seaweeds in fish feed composition may lead to reduced performance. This may be related to the concentration of non-amilaceous carbohydrates in BSM. According to Meurer and Hayashi (2003), non-amilaceous carbohydrates have a negative effect on fish performance, while small amounts may result in the improvement of some performance parameters.

Another important factor to evaluate for $\mathrm{BSM}$ is its role as an additive, either as a food complement, an agglutinant, an immune stimulant agent, or a prebiotic. Greater attention should be paid to the study of BSM as a prebiotic, which is a non-digestible food component that affects the host positively by selectively stimulating the proliferation or the activity of desirable bacteria in the colon and possibly inhibiting the multiplication of pathogens and guaranteeing further benefits to the animal's health (Saad, 2006). According to Budiño et al. (2005), there is some evidence that prebiotics may result in anatomical changes in the digestive tract and stimulate the immune system (Silva and Nörnberg, 2003).

The evaluation of fish growth in experimental units by means of intermediate weighing demonstrated that the treatments with BSM stood out after the fifth week and the results became pronounced in the last week, which may be indicative that the tested ingredient may be effective over longer periods in the species. The BSM has good potential as a feed additive for Nile tilapia fingerlings. Nevertheless, an investigation of its application during other phases of the Nile tilapia growth, over longer treatment periods, as well as under sanitary challenging to verify the effect of BSM on immune responses and production performance, is important for its commercial use in Nile tilapia cultures.

\section{CONCLUSIONS}

The addition of BSM at the level of $20 \mathrm{~g}$ $\mathrm{kg}^{-1}$ feed does not result in growth loss and improves the feed conversion ratio and carcass yield in Nile tilapia during the fingerling period.

\section{ACKNOWLEDGMENTS}

The authors thank Conselho Nacional de Desenvolvimento Científico e Tecnológico $(\mathrm{CNPq})$ for scholarships provided and the $3^{\text {rd }}$ Regional Agency of CODEVASF at Petrolina, particularly for the support of fishing engineers of the Bebedouro Fish Culture Station, Rozzano Antônio Cavalcante Reis de Figueiredo and Marcelo Barbalho, who supplied Nile tilapia fingerlings. Special thanks go to Mr. José Ramos S. Filho from VALEAGRO for the financial support in the assembly and execution of the present experiment.

\section{REFERENCES}

Allen, V.G.; Pond, K.R.; Saker, K.E.; Fontenot, J.P.; Bagley, C.P.; Ivy, R.L.; Evans, R.R.; Brown, C.P.; Miller, M.F.; Montgomery, J.L.; Dettle, T.M. and Webster, D.B. 2001. Tasco-Forage: III. Influence of a seaweed extract on performance, monocyte immune cell response, and carcass characteristics in feedlot-finished steers. J Anim Sci, 79: 1032-1040.

Alves Filho, F.M.; Santos, L.D.; Silva, L.C.R.; Bombardelli, R.A. e Meurer, F. 2011. Alga marrom (Ascophyllum nodosum) para alevinos de tilápia do Nilo. Rev Bras Saude Prod Anim, 12: 10951102.

Archer, G.S.; Friend, T.H.; Caldwell, D.; Ameiss, K. and Krawczel, P.D. 2007. Effect of the seaweed Ascophyllum nodosum on lambs during forced

Archivos de zootecnia vol. 62, núm. 237, p. 107. 
walking and transport. J Anim Sci, 85: 225-232. Berteau, O. and Mulloy, B. 2003. Sulfated fucans, fresh perspectives: structures, functions, and biological properties of sulfated fucans and an overview of enzymes active toward this class of polysaccharide. Glycobiology, 13: 29-40.

Boscolo, W.R.; Hayashi, C. e Meurer, F. 2002. Digestibilidade aparente da energia e nutrientes de alimentos convencionais e alternativos para a tilápia do Nilo (Oreochromis niloticus, L.). Rev Bras Zootecn, 13: 539-545.

Branden, K.W.; Blanton, J.R.; Montgomery, J.L.; Van Santen, E.; Allen, V.G. and Miller, M.F. 2007. Tasco supplementation: effects on carcass characteristics, sensory attributes, and retail display shelf-life. J Anim Sci, 85: 754-768.

Budiño, F.E.L.; Thomaz, M.C.; Kronka, R.N.; Nakaghi, L.S.O.; Tucci, F.M.; Fraga, A.L.; Scandolera, A.J. and Huaynate, R.A.R. 2005. Effect of probiotic and prebiotic inclusion in weaned piglet diets on structure and ultrastructure of small intestine. Braz Arch Biol Techn, 48: 921-929.

Davies, S.J.; Brown, M.T. and Camilleri, M. 1997. Preliminary assessment of the seaweed Porphyra purpurea in artificial diets for thicklipped grey mullet (Chelon labrows). Aquaculture, 152: 249-258.

El-Sayed, A.M. 2006. Tilapia culture. CABI Publishing. Oxford. 277 pp.

Fike, J.H.; Saker, K.E.; O'Keefe, S.F.; Marriott, N.G.; Ward, D.L.; Fontenot, J.P. and Veit, H.D. 2005. Effects of (a seaweed extract) and heat stree on $\mathrm{N}$ metabolism and meat fatty acids in wether lambs fed hays containing endophyte-infected fescue. Small Ruminant Res, 60: 237-245.

Fleurence, J. 1999. Seaweed proteins: biochemical, nutritional aspects and potential uses. Trends Food Sci Tech, 10: 25-28.

Gabrielsen, B.O. and Austreng, E. 1998. Growth, product quality and immune status of Atlantic salmon, Salmo salar L., fed wet feed with alginate. Aquac Res, 29: 397-401.

Gardiner, G.E.; Campbell, A.J.; O'Doherty, J.V.; Pierce, E.; Lynch, P.B.; Leonard, F.C.; Stanton, C.; Ross, R.P. and Lawlor, P.G. 2008. Effect of Ascophyllum nodosum extract on growth performance, digestibility, carcass characteristics and selected intestinal microflora populations of grower-finisher pigs. Anim Feed Sci Tech,
141: 259-273

Kannan, G.; Saker, K.E.; Terrill, T.H.; Kouakou, B.; Galipalli, S. and Gelaye, S. 2007a. Effect of seaweed extract supplementation in goats exposed to simulated preslaughter stress. Small Ruminant Res, 73: 221-227.

Kannan, G.; Terrill, T.H.; Kouakou, B. and Galipalli, S. 2007b. Blood metabolite changes and live weight loss following brown seaweed extract supplementation in goats subjected to stress. Small Ruminant Res, 73: 228-234.

Kumar, C.S.; Gtanesan, P.; Suresh, P.V. and Bhaskar, N. 2008. Seaweeds as a source of nutritionally beneficial compounds. A review. $J$ Food Sci Tech Mys, 45: 1-13.

Leupp, J.; Caton, J.S.; Soto-Navarro, S.A. and Lardy, G.P. 2005 Effects of cooked molasses blocks and fermentation extract or brown seaweed meal inclusion on intake, digestion, and microbial efficiency in steers fed lowquality hay. J Anim Sci, 83: 2938-2945.

Meurer, F.; Costa, M.M.; Barros, D.A.D.; Oliveira, S.T.L. and Paixão, P.S. 2009. Brown propolis extract as a growth promoter of Nile tilapia (Oreochromis niloticus, Linnaeus 1758) fingerlings. Aquac Res, 40: 603-608.

Meurer, F. e Hayashi C. 2003. Polissacarídeos não amiláceos na nutrição de peixes. Revisão. Arq Ciênc Vet Zool Unipar, 6: 127-138.

Meurer, F.; Hayashi, C. e Boscolo, W.R. 2003. Digestibilidade aparente de alguns alimentos protéicos pela tilápia do Nilo (Oreochromis niloticus, L.). Rev Bras Zootecn, 32: 18011809.

Meurer, F.; Hayashi, C.; Boscolo, W.R.; Santos, L.D.; Wolf, L. e Colpini, L.M.S. 2007. Exigência de proteína digestível para juvenis de tilápia do Nilo (Oreochromis niloticus) em baixa temperatura. Rev Cient Prod Anim, 9: 53-64.

Meurer, F.; Oliveira, S.T.L.; Santos, L.D.; Oliveira, J.S. e Colpini, L.M.S. 2010. Níveis de oferta de pós-larvas de tilápia do Nilo para alevinos de pacamã (Lophiosilurus alexandri). Rev Bras Ciênc Agrár, 5: 111-116.

Mustafa, M.G.; Wakamatsu, S.; Takeda, T.A.; Umino, T. and Nakagawa, H. 1995. Effects of algae meal as feed additive on growth, feed efficiency, and body composition in red sea bream. Fish Sci, 61: 25-28.

Nakagawa, H.; Umino, T. and Tasaka, Y. 1997.

Archivos de zootecnia vol. 62, núm. 237, p. 108. 


\section{BROWN SEAWEED MEAL TO NILE TILAPIA FINGERLINGS}

Usefulness of Ascophyllum meal as a feed additive for red sea bream, Pagrus major. Aquaculture, 151: 275-281.

Rostagno, H.S.; Albino, L.F.T.; Donzele, J.L.; Gomes, P.C.; Ferreira, A.S.; Oliveira, R.F. e Lopes, D.C. 2000. Tabelas brasileiras para aves e suínos: composição de alimentos e exigências nutricionais. $1^{\underline{a}}$ ed. UFV/DZO. Viçosa. $141 \mathrm{pp}$.

Saad, S.M.I. 2006. Probióticos e prebióticos: o estado da arte. Rev Bras Cienc Farm, 42: 1-16.

Saker, K.E.; Fike, J.H.; Veit, H. and Ward, D.L. 2004.

Brown seaweed- $\left(\right.$ Tasco $^{\mathrm{TM}}$ ) treated conserved forage enhances antioxidant status and immune function in heat-stressed wether lambs. J Anim Physiol An N, 88: 122-130.

Sharp, G.J. 1986. Ascophyllum nodosum and its harvesting in Eastern Canada. In: Case studies of seven commercial seaweed resources. FAO Tech Rep, 281: 3-46.

Silva, D.J. e Queiroz, A.C. 2002. Análises de alimentos (métodos químicos e biológicos). Editora UFV. Viçosa. $235 \mathrm{pp}$.

Silva, L.P. e Nörnberg, J.L. 2003. Prebióticos na nutrição de não-ruminantes. Cienc Rural, 33: 983-990.

Turner, J.L.; Dritz, S.S.; Higgins, J.J. and Minton, E. 2002. Effects of Ascophyllum nodosum extract on growth performance and immune function of young pigs challenged with Salmonella typhimurium. J Anim Sci, 80: 1947-1953.

UFV. 2000. Universidade Federal de Viçosa. SAEG. Sistema para análises estatísticas e genéticas. Versão 8.0. UFV. Viçosa, MG. 